\title{
A PRELIMINARY FRAMEWORK FOR EXPEDITING ENERGY EFFICIENCY RETROFITS (EERs) USING ALTERNATIVE FINANCING IN INDONESIAN CITIES
}

\author{
Novi Bramono ${ }^{1 *}$, Amy Kim² ${ }^{2}$, Mohammed Ali Berawi ${ }^{3}$ \\ ${ }^{1}$ Independent Researcher, IDX Tower 2 9th fl, SCBD Jakarta, 12190, Indonesia \\ ${ }^{2}$ Civil and Environmental Engineering, University of Washington, Seattle, WA 98195 USA \\ ${ }^{3}$ Department of Civil Engineering, Faculty of Engineering, Universitas Indonesia, Depok 16424, \\ Indonesia
}

(Received: October 2018 / Revised: November 2018 / Accepted: January 2019)

\begin{abstract}
Existing buildings have a huge opportunity concerning energy and water savings potential in Indonesia. In Jakarta alone, it is estimated that least 90 percent of total buildings were built before 2014. The general perception of having a more energy-efficient existing building is associated with a higher upfront cost and how to finance it. To overcome these issues, incentives have been considered as one crucial pull factor to implement energy efficiency retrofits (EERs). To identify types of incentive that might work in Indonesia city context, it is essential to develop a framework that can be adopted nationally. This research aims to identify the key factors that can be integrated into the framework. To do that, an extensive electronic literature review, added with archival study and case studies analysis using Jakarta as a model for Indonesian cities in implementing green building code. A comprehensive analysis of favorable policy, existing building stock data, study on possible incentive mechanism and added with case studies are presented. From the analysis, it is concluded existing supporting policy, potential energy savings from existing building stock and local capacity are equally important factors. It is expected that these findings will be utilized as the critical factors for developing a framework on expediting EERs to be adopted in Indonesia cities, which is an important key to unlock the potential energy savings from existing building stock.
\end{abstract}

Keywords: Existing buildings; Energy efficiency retrofits; Framework; Incentives

\section{INTRODUCTION}

It is estimated that buildings globally play a significant role in the number of energy people use (Center for Clean Air Policy [CCAP], 2018; International Energy Agency [EA], 2018; Architecture 2030, 2018). Reducing energy consumption in buildings could significantly improve overall energy efficiency (IEA, 2018; Architecture 2030, 2018). United Nations Environmental Program (UNEP, 2016) in Global Status Report 2016, stated that 30 to 40 percent of all worldwide energy use, with associated greenhouse gas emissions (GHGs), is associated with buildings. Reducing the energy consumed by buildings is involved, and universal solutions to ensure energy efficiency are challenging.

*Corresponding author's email: ntibramono@gmail.com, amyakim@uw.edu 
The Indonesia National Government initiated an energy-efficient building policy in Indonesia in the early 2010s (Instruksi Presiden Republik Indonesia [Inpres], 2011; Kementerian Energi dan Sumber Daya Mineral [ESDM], 2012) targeting government buildings both new and existing to achieve 20 percent more energy savings against the previous year. It has been successful and encouraged further policy development dedicated to energy-efficient building practices. In 2012 (Jakarta 2016), Jakarta pioneered the first mandatory green building code focused on energy and water efficiency for new buildings and benchmarked energy and water consumption data from existing building stock (Jakarta Green Building, 2016). Inspired by Jakarta's leadership in green building, the Ministry of Public Works and Housing launched National Green Building Code No. 02/2015 which has been referred by Indonesian cities to implement local green building policy (Berita Satu, 2015). Soon afterward, leading metropolitan cities such as Bandung, Makassar, Surabaya, and Semarang stepped into energy-efficient policy development (Kompas.com, 2016).

While energy efficiency from new construction buildings has shown promising impact (Jakarta Green Building 2016), question remain is how energy efficiency can be received from existing buildings (Jaya Raya and International Finance Corporation, 2016). Existing building stock offers more considerable potential savings due to its high volume and the availability of lowcost technology (Building Efficiency Initiative, 2010) and should be prioritized (Ruparantha et al. 2016). However, Indonesian cities have numerous serious challenges in regulating existing building stock to be more energy efficient (WBCSD, 2016). Loosely enforced regulations with the absence or incentives have made this even more challenging. In addition, retrofitting existing buildings also requires significant upfront capital, and can be paid back through lower building energy costs. (Sweatman \& Managan 2010) Also, can save up to 40 percent by reducing their energy use (Biello, 2011). In addition to reducing energy bills, retrofitting existing buildings provides other opportunities such as job creation and resiliency to future climate change (Biello 2011). If the market for existing buildings has potential, then why it is not happening? Sweatman \& Managan (2010) further this finding by identifying that adequate finance, supportive policies, and broad-scale education initiatives could be the keys to unlock energy savings from existing buildings.

In 2016, Jakarta renewed its strategy to achieve higher energy savings in 2030 against Business as Usual (BaU) scenario (no-code scenario), entitled 30:30 Commitment (30:30C). It aims to achieve each 30 percent savings from energy, GHGs and water consumption from the buildings sector. It targets all new buildings started in 2017 onwards to comply with green building code, and 60 percent of existing buildings required to be more energy efficient. Based on the calculation and predictions, it is estimated that more than 3,785 GWh energy savings can be retrieved in 2030 (Jakarta Green Building, 2016). From that number, existing buildings will contribute 31 percent out of total energy savings.

Incentives are required to encourage building owners and developers in understanding longterm benefits of having their existing buildings retrofitted (Sweatman \& Managan, 2010, Biello, 2011; Energy Sector Management Assistance Program [ESMAP], 2014). The current perceptions of retrofitting existing buildings are not always positive, mostly due to nontechnical issues such as lack of knowledge and limited access to available funding, which could hamper the long-term policy commitment to high-efficiency buildings (Biello, 2011). Jakarta has outlined the importance of incentivizing existing building retrofit as one of the key factors to achieve its 30:30C's target and recognized it as one of the essential factor, as well as Bandung and Semarang code. With many cities are following this step, it is urgent to provide a clear framework to determine what kind of incentive for existing building retrofits can be suitable for an Indonesian context. 
The primary purpose of this study is to identify some key factors to consider the development of a preliminary framework for expediting energy efficiency retrofits (EERs) using incentives as a financing alternative in Indonesian cities. To achieve these identifiable targets, specific objectives were set as follows: a. Analyze the current policy in Jakarta as a model for Indonesian cities in implementing EER-related policy, b. Analyze the possibility of determining what works and what does not work in available incentive alternatives for other Indonesian cities; and c. Investigate lessons learned from several case studies.

\section{METHODS}

The research was conducted in two phases. First, to identify opportunities in implementing incentives for EERs on existing buildings and the second analyzed the accepted findings as the critical factors in developing a framework for expediting EERs in Indonesian cities. Data analysis is delivered using electronic literature reviews and archival data as the mean to optimize outputs. Case studies are to be presented and studied further to gain more insights into how incentives-related EERs are implemented in a different context.

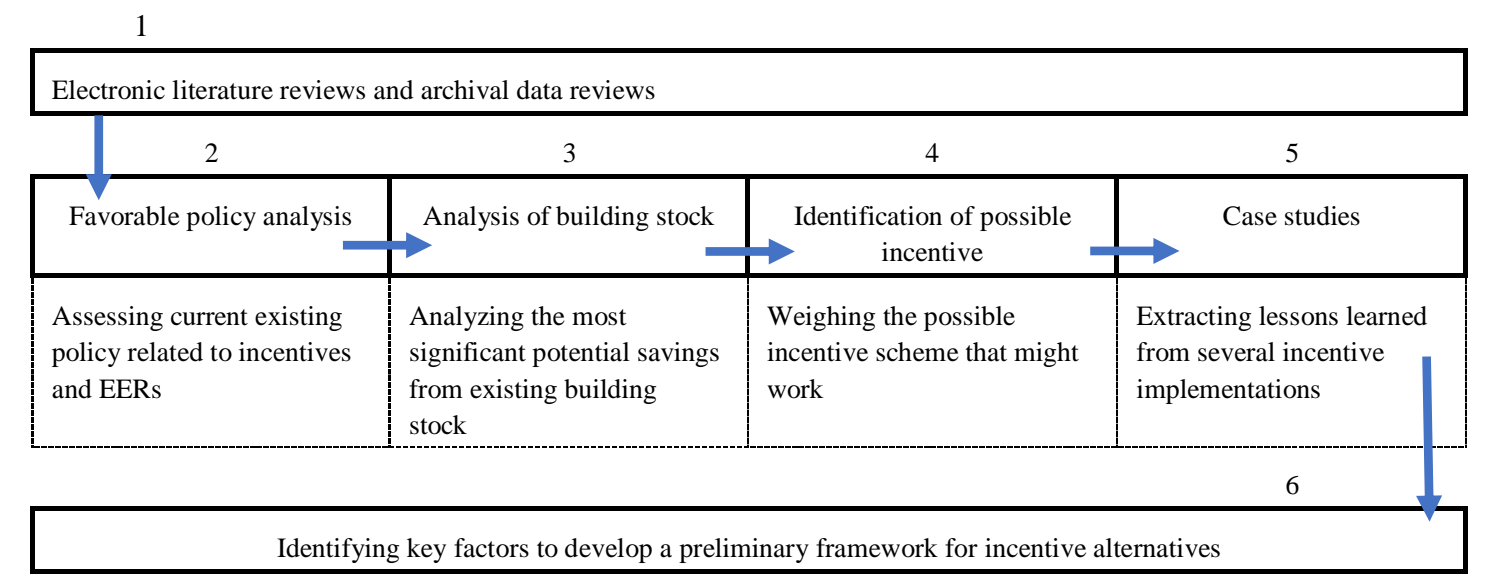

Figure 1. The Study Methodology

The research followed data analysis as shown in Figure 1. First, electronic literature reviews and archival data reviews initiated to gain relevant background, theoretical framework related to incentives and EERs implementation and current policy development in Indonesia context and Jakarta in particular. Second, all collected data is examined current existing policy for incentives related to EERs whether it is favorable or not. Using an adaptation from literature review, identification of existing policies is determined.

Third, the research analyzes of building stock against 30:30C target from an existing building in 2030, to gain a deeper understanding of what building's type should be prioritized. Fourth, from the literature review on incentivizing building sector, an adaptation is developed to identify the possible incentive mechanism which might work. Fifth, to study the lesson-learned from three countries (Philippines, Singapore, and China) in the East Asia Pacific which implementing incentive and/or EERs related. So finally, all the findings from one to the fifth step, are synthesized to conclude the key factors for developing a framework for incentive alternatives.

\section{RESULTS AND DISCUSSION}

\subsection{Favorable Policy Analysis}

Based several successful examples in implementing EERs policy, there are vital factors identified, which are the availability of standards, the presence of direct financial assistance, market-based instruments, and efforts in removing hurdles (Sweatman \& Managan, 2010). 


\section{Using this approach and adapting it, a policy analysis was developed to assess Jakarta policy context (Table 1), as follows:}

Table. 1. Identification of Favorable Policies to Promote EERs in Jakarta.

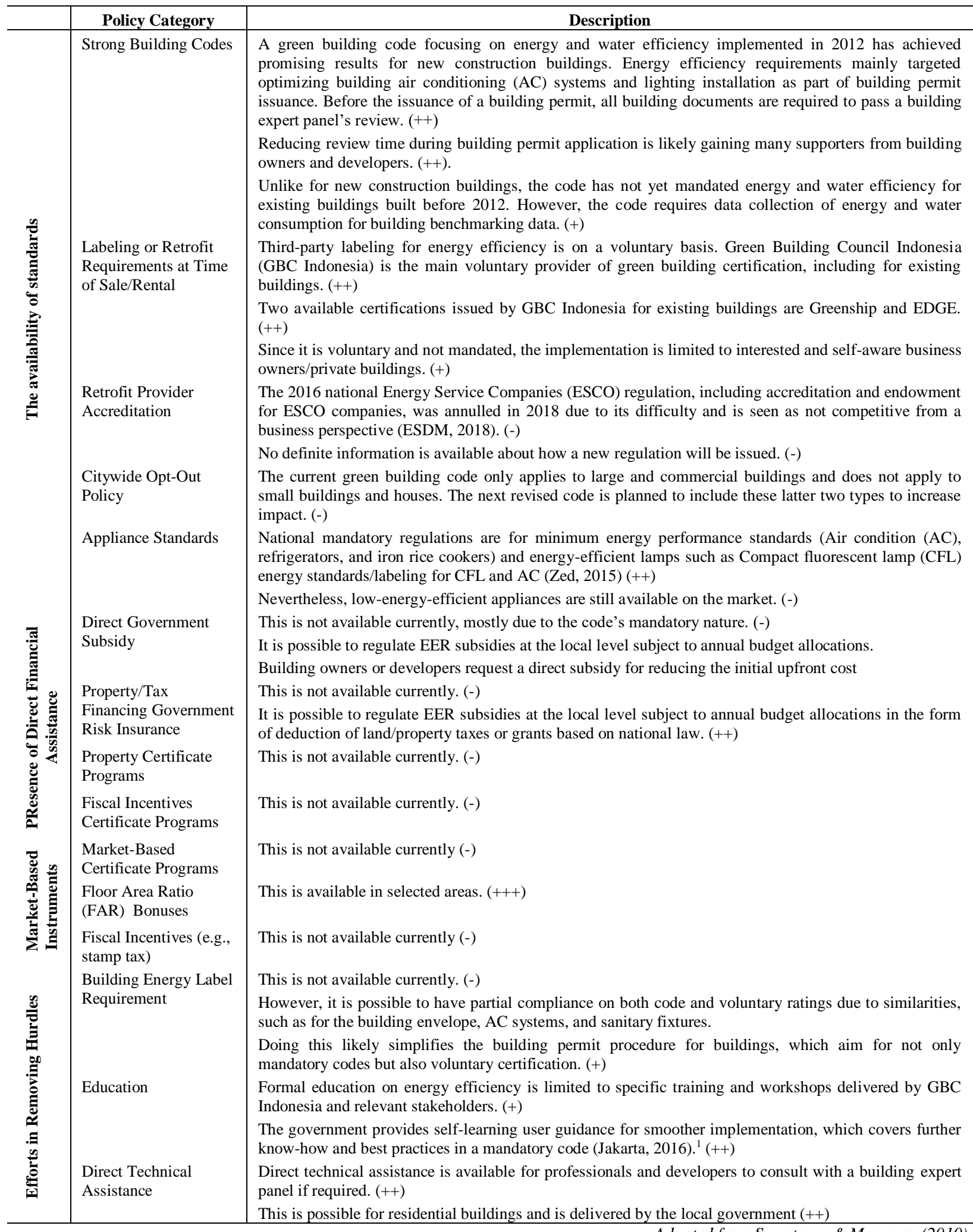

Legend:

+ favourable, ++ more favourable, +++ most favourable

- Less favorable, --least favorable, --- lesser favorable 
The analysis conducted in Table 1 concluded that even though the current policy seems strong, there is no guarantee that energy-efficiency savings will be delivered due to a weak monitoring system. Third parties that perform building retrofit labeling must be viewed as future potential partners. The building permit procedure is in place, assisted by the established building expert panel, and should be utilized in incentive-related code compliance. The table also shows that direct financial assistance is not yet available. However, there is some small potential in providing land/property tax or direct grants in the future since this type of tax has already regulated at the national level, but direct financial assistance will require further study. Without market-based tools to interest building owners and project owners, it would be difficult to encourage them to go beyond the mandatory code. However, the possibility of density bonuses (FAR) in selected areas would encourage developers. Last, further access to education and the provision of technical assistance from the government or relevant stakeholders might be useful to encourage higher energy efficiency for building projects. The widely used green building website makes it easier for engineers and the public to comply with the code.

\subsection{Analysis of Building Stock}

This analysis identifies how much building stock can contribute to potential energy efficiency savings. The data were retrieved from the Jakarta Building Agency using several assumptions:

- The calculation is developed based on the specific building types mandated by the code, which are apartments, offices, and commercials above $50.000 \mathrm{~m}^{2}$, hotels, and hospitals above $20.000 \mathrm{~m}^{2}$ and schools above $10.000 \mathrm{~m}^{2}$;

- The construction growth rate per annum is set at a moderate 2.5 percent.

- The target is that 100 percent of the buildings built after 2017 comply with the green building code and 60 percent of existing buildings become more energy and water efficient.

- The green building code is scheduled to be revised three times in 2017, 2024, and 2029, focusing in reduce each of building type's size to get more energy savings.

Table 2. Breakdown of BaU Energy Consumption and Energy Savings in Jakarta for 30:30C.

\begin{tabular}{|c|c|c|c|c|}
\hline Scenario & Items & $\begin{array}{l}\text { Total Size } \\
\quad\left(\mathbf{m}^{2}\right)\end{array}$ & $\begin{array}{c}\text { Energy } \\
\text { Amount }\end{array}$ & Units \\
\hline \multirow[t]{3}{*}{ Business as Usual } & $\begin{array}{l}\text { Existing } \\
\text { building }\end{array}$ & $17,757,516$ & 7,080 & GWh \\
\hline & $\begin{array}{c}\text { New } \\
\text { construction }\end{array}$ & $15,554,532$ & 6,144 & GWh \\
\hline & Total & $33,312,048$ & 13,224 & GWh \\
\hline \multirow[t]{3}{*}{$\begin{array}{c}\text { Energy } \\
\text { Consumption }\end{array}$} & $\begin{array}{l}\text { Existing } \\
\text { building }\end{array}$ & $17,757,516$ & 5,918 & GWh \\
\hline & $\begin{array}{c}\text { New } \\
\text { construction }\end{array}$ & $15,554,532$ & 3,521 & GWh \\
\hline & Total & $33,312,048$ & 9,439 & GWh \\
\hline \multirow[t]{3}{*}{ Energy Savings } & $\begin{array}{l}\text { Existing } \\
\text { building }\end{array}$ & $17,757,516$ & 1,162 & GWh \\
\hline & $\begin{array}{c}\text { New } \\
\text { construction }\end{array}$ & $15,554,532$ & 2,623 & GWh \\
\hline & $\begin{array}{c}\text { Total } \\
\text { Percent saving } \\
\text { vs. BaU }\end{array}$ & $33,312,048$ & $\begin{array}{c}3785 \\
29\end{array}$ & $\begin{array}{c}\text { GWh } \\
\text { percent }\end{array}$ \\
\hline
\end{tabular}


Table 2 shows the breakdown of the projected building size, $\mathrm{BaU}$ (no-code scenario), energy consumption, and savings from 30:30C. From this Table, it can be concluded that even existing buildings have higher in total energy consumption (53 percent), the expected energy savings from existing buildings is about 20 percent while new construction is almost 60 percent. This might be resulted by perceived difficulties (Biello, 2011) led to lack of interest from building owners (Landman, 1999), the absence of government support (Sweatman \& Managan, 2010), and financial concerns by the relevant stakeholders by the time the 30:30C was developed (Landman, 1999). However, considering that existing building's population is estimated to be between 90 and 95 percent of the total building stock, it has much potential yet to be used.

Table 3 shows that the building type that has the highest energy consumption in Jakarta is large and commercial buildings consisting of apartments, offices, and large retail buildings. Even though hotels and hospitals have higher energy efficiency impacts than apartments and offices, they have lower influence because the percentage of them is very low.

Table 3. Percent of Building Types from 30:30C

\begin{tabular}{lc}
\hline \multicolumn{1}{c}{ Building Type } & Percentage \\
\hline Apartments, offices, and large retail stores & 80.44 percent \\
Hotels and hospitals & 17.15 percent \\
Schools & 2.44 percent \\
\hline \multicolumn{2}{c}{ Source: Author analysis based on DPK Jakarta (2016) }
\end{tabular}

Based on the analysis from Table 2 and Table 3, it can be concluded that:

- EERs from existing buildings is a market with high potential savings to be tapped, with targeted savings of 1,162 GWh from the 7,080 GWh from the BaU scenario.

- Apartments, offices, and large retail buildings dominating the existing population and need to be addressed appropriately regarding what types of incentive could be provided for building occupants, owners, managers, or to private sectors, i.e., do they require split incentives? Would it be preferable to have financial or non-financial ones? Would they adapt to performance-based incentives? These questions require careful consideration.

\subsection{Identification of Possible Incentive Scheme}

An incentive is "an inducement or supplemental reward that serves as a motivational device for a desired action or behavior" (Business Dictionary n.d.), which can be interpreted as a reward for doing something exceeding the expectation. This interpretation also aligns with a report by the World Bank Group and International Bank for Reconstruction and Development (IBRD) (2015), which emphasizes that incentives should be applied for to encourage better performance (International Bank for Reconstruction and Development, 2015). It categorizes three major incentives, which can individually or a combined application, as follows:

- government-process improvement,

- land use changes, and

- financial.

Adapted from this approach, the incentive mechanisms shown in table 4 are prioritized based on its relation to fiscal power, period terms, and the most impacted beneficiaries. In principle, short term is representing on how local government could deliver the incentives without having extra efforts, while mid-term and long-term requires external coordination added with policy intervention and might be attractive for buildings to go beyond mandatory code. Combined incentives can be an exciting option for selected and strategic projects. The presence of a 
building expert panel for building and occupancy permits would be valuable in delivering the dedicated technical assistance assigned by the Jakarta Government.

Table 4 Identification of Possible Incentive Scheme for EERs of Existing Buildings

\begin{tabular}{|c|c|c|c|}
\hline \multicolumn{2}{|c|}{ NON-FISCAL INCENTIVES } & \multicolumn{2}{|c|}{ FISCAL INCENTIVES } \\
\hline \multicolumn{2}{|c|}{ Short-Term (2-3 years) } & \multicolumn{2}{|c|}{ Short-Term (2-3 years) } \\
\hline Type & Beneficiaries & Type & Beneficiaries \\
\hline $\begin{array}{l}\text { Expedited time for } \\
\text { Building and/or } \\
\text { Occupancy Permit }\end{array}$ & $\begin{array}{l}\text { Building owners, } \\
\text { engineers }\end{array}$ & $\begin{array}{l}\text { Reduction Building } \\
\text { Permit fee }\end{array}$ & $\begin{array}{l}\text { Building owners, } \\
\text { contractors }\end{array}$ \\
\hline $\begin{array}{l}\text { Technical assistance } \\
\text { (selected projects) }\end{array}$ & $\begin{array}{l}\text { Engineers, building } \\
\text { owners }\end{array}$ & $\begin{array}{l}\text { Reduction of local } \\
\text { building and/or land } \\
\text { taxes }\end{array}$ & $\begin{array}{l}\text { Building } \\
\text { management, } \\
\text { owners }\end{array}$ \\
\hline $\begin{array}{l}\text { Recognition (selected } \\
\text { projects) }\end{array}$ & $\begin{array}{l}\text { Building management, } \\
\text { owners, tenants }\end{array}$ & & \\
\hline \multicolumn{2}{|c|}{ Mid-Term (4-5 years) } & \multicolumn{2}{|c|}{ Mid-Term (4-5 years) } \\
\hline Type & Beneficiaries & Type & Beneficiaries \\
\hline $\begin{array}{l}\text { Density bonuses (Floor } \\
\text { area ratio/FAR) }\end{array}$ & Building owners & $\begin{array}{l}\text { Grants (including } \\
\text { subsidy) }\end{array}$ & $\begin{array}{l}\text { Building } \\
\text { management, energy } \\
\text { service companies, } \\
\text { owners }\end{array}$ \\
\hline
\end{tabular}

\begin{tabular}{|c|c|c|c|}
\hline \multicolumn{2}{|c|}{ Long-Term (> 5 years) } & \multicolumn{2}{|c|}{ Long-Term (> 5 years) } \\
\hline Type & Beneficiaries & Type & Beneficiaries \\
\hline N/A & N/A & $\begin{array}{l}\text { Discount for energy- } \\
\text { efficient products }\end{array}$ & $\begin{array}{l}\text { Building } \\
\text { management, energy } \\
\text { service companies, } \\
\text { owners }\end{array}$ \\
\hline
\end{tabular}

Combined (Short to Mid-Term for flagship projects, can be cumulative or alternative)

Technical assistance + Reduction of Building Permit fee + Reduction of local building and/or land taxes + Expedited time for Building permit

Source: Author analysis based on World Bank Group and IBRD (2015)

\subsection{Case Studies}

\subsubsection{Philippines}

Cities are leaders in energy efficiency implementation but have limited capacity. Building Ecologically Responsive Design Excellence (BERDE) in the Philippines started in 2009 and was developed by the Philippines Green Building Council as a voluntary green building rating system and has been adopted as a guide to developing policies and programs for the green building sector.

At the city level, local governments issued mandatory green building ordinances to encourage better practices. To have more significant impacts and enthusiasm from project owners, incentives are introduced and may be given to project owners if the project surpasses the code requirements. Five cities that have issued and implemented this policy are Quezon, Mandaluyong, Manila, Pasig, and Mandaue (Philippines Green Building Council, 2018). In Mandaluyong, (Mandaluyong City Government n.d.) which issued a green building code in 2014, incentives are provided based on certificate issuance stages (Republic of the Philippines, Mandaluyong City n.d.) related to Permit. Pre-compliance Certificate will be issued before the 
building is to be constructed, while the Occupancy Permit will be issued when building's construction is completed and ready to be operated. The incentive will be granted if the project owner or developer's design documents comply with the Green Building Code. For those buildings, they automatically granted specific an additional floor area ratio bonus (FAR) following the dedicated zone classification.

Project owners or developers who secure both Pre-compliance and Occupancy permit are automatically granted an additional 50 percent discount on property tax on equipment and an additional 50 percent on property tax. Both discounts only apply for the first year of payment of taxes. Unfortunately, no public records are available on how many buildings or incentives are granted to project owners or developers in those cities. The positive thing is that the cities have inspired the development and issuance of the Philippines Green Building Code in 2016. However, this national code only acts as a general reference and seems to transfer incentive issuance to the local level because it does not contain any articles on incentives.

\subsubsection{Singapore}

Dedicated incentives and financing EERs address specific challenges. Realizing its scarcity of land and other resources, the Singapore Government proclaimed an energy-efficiency building policy in the late 1990s. Unlike other countries that started without long-term planning for sustainability, Singapore developed a series of master plans, which indicate clear targets with specific milestones. It aims 80 percent of all building gross floor area will be green in 2030 using Green Mark Certification system delivered by the Building and Construction Authority (Building and Construction Authority [BCA], 2018).

To achieve the target, incentivizing and financing existing buildings are one top-notch program prepared by BCA that varies for specific needs for each building and pool of funding. The most updated incentives for existing buildings are contained under three main schemes that address each specific challenge:

- the Health Check Scheme, a subsidized energy audit program provided for buildings with more than $2000 \mathrm{~m}^{2}$ gross floor area that apply for Green Mark Certification;

- an enhanced version of the Green Mark Incentive Scheme for Existing Buildings and Premises, which aims to encourage EERs to achieve energy performance and Green Mark certification. It is dedicated to owners of existing buildings owned or partially owned by small and medium enterprises, and non-public buildings such as non-government organizations (NGOs) and religious buildings, to conduct energy improvement works including chiller or a variable refrigerant flow (VRF) and building optimization works; and

- Building Retrofit Energy Efficiency Financing, a pilot financing (loan) project in which BCA partnered with a few financial institutions and aims to provide upfront capital for EERs to achieve a minimum Green Mark certified level.

\subsubsection{China}

Having no mandatory code for EERs makes it challenging to achieve desirable targets. China has doubled its floor space from 1996 to 2011 due to tremendous economic growth. Consequently, energy consumption has increased by over 40 percent since 1990 from the buildings sector (Yu et al. 2014). Gradual policy improvement in mandatory building codes started in the 1980s and has been a driving force behind energy efficiency measurement being introduced and becoming more stringent. Policy improvements aligned with the Green Building Action Plan and National New-Type Urbanization 2010-2014 heavily influence (CBRE 2015) local governments (provinces and municipalities) to quickly develop a policy to implement energy-efficient buildings (CBRE, Ltd. 2015). 
With its national Three Star Rating System, the China Central Government encourages building construction to design, build, and operate beyond the mandatory code. In addition, the vast size of the country has necessitated a building code, and energy efficiency code specifically developed to respond to each climate's needs (Yu et al., 2014). The Three Star Rating System has also become the primary reference for local provinces and municipalities to measure building performance.

Due to large inefficient buildings built before the code and energy efficiency were introduced, it opens significant opportunities for building retrofits. The government also mandated building retrofits of residential buildings that should be conducted by the local government each year, and aids in financing these projects, focusing on insulation, windows, and heat distribution. The China Central Government has also set a goal to increase the scale of retrofits of government and state-owned buildings and recognizes the importance of incentivizing green buildings in transforming the market.

Table 5 Lesson learned from Case Studies.

\begin{tabular}{|c|c|c|c|}
\hline & Philippines & Singapore & China \\
\hline Initiator & $\begin{array}{l}\text { City level ( } 5 \text { cities are } \\
\text { implementing Green } \\
\text { Building Code with energy - } \\
\text { efficiency is the most } \\
\text { important part) }\end{array}$ & City-national level & National-level \\
\hline $\begin{array}{l}\text { Type of incentives } \\
\text { implemented for } \\
\text { existing building }\end{array}$ & $\begin{array}{l}\text { Not available for existing } \\
\text { buildings, only available for } \\
\text { new construction }\end{array}$ & $\begin{array}{l}\text { A specific incentive for } \\
\text { specific existing buildings } \\
\text { aims to capture the } \\
\text { designated energy savings, } \\
\text { for instance: combined } \\
\text { technical assistance to get } \\
\text { first green certification } \\
\text { (Health Check Scheme), the } \\
\text { incentive for buildings owned } \\
\text { by small or medium } \\
\text { enterprises, NGOs to upgrade } \\
\text { machinery system, and loan } \\
\text { incentives partnered with } \\
\text { financial institutions }\end{array}$ & $\begin{array}{l}\text { No records on incentives } \\
\text { for existing building, } \\
\text { however, National } \\
\text { government provides } \\
\text { incentives for } \\
\text { manufacturers related to } \\
\text { building systems: AC } \\
\text { systems and energy- } \\
\text { efficient lamps and private } \\
\text { sectors (ESCO) and smart } \\
\text { city investments }\end{array}$ \\
\hline Means of control & $\begin{array}{l}\text { Building permit and } \\
\text { occupancy permit }\end{array}$ & $\begin{array}{l}\text { Building permit and } \\
\text { occupancy permit }\end{array}$ & Building permit \\
\hline $\begin{array}{l}\text { Availability of } \\
\text { long-term } \\
\text { planning }\end{array}$ & $\begin{array}{l}\text { No records are shown in the } \\
\text { literature }\end{array}$ & $\begin{array}{l}\text { Driven by series of Green } \\
\text { Building Masterplan, } \\
\text { targeting } 80 \% \text { of all buildings } \\
\text { comply with Green Mark } \\
\text { standard in } 2030\end{array}$ & $\begin{array}{l}\text { Driven by c Green Action } \\
\text { Plan to be referred by local } \\
\text { level }\end{array}$ \\
\hline $\begin{array}{l}\text { Assumed } \\
\text { Challenges }\end{array}$ & $\begin{array}{l}\text { Even though cities are the } \\
\text { main policy drivers, however } \\
\text { without National intervening } \\
\text { policy and support further } \\
\text { fiscal allocation, would be } \\
\text { difficult to get the existing } \\
\text { incentive mechanism } \\
\text { expanded to existing } \\
\text { buildings. }\end{array}$ & $\begin{array}{l}\text { To persuade existing building } \\
\text { owners to take the first green } \\
\text { certification due to } \\
\text { certification fees. }\end{array}$ & $\begin{array}{l}\text { The absence of mandatory } \\
\text { retrofitting existing } \\
\text { building would make } \\
\text { difficulties to influence } \\
\text { cities to gain additional } \\
\text { energy savings. }\end{array}$ \\
\hline
\end{tabular}

The government learned from its early implementation (CBRE 2015), started in 2012, and provides financial incentives for new construction buildings passing two stars or three stars, 
encouraging building owners and developers to exceed the standard first-star code (CBRE, Ltd. 2015). This voluntary green building with financial incentives is expected to multiply in the future and open opportunities for cities to make this combination mandatory, which is possible in China's codes and standards (Wei, 2013) and being introduced to rural buildings.

EERs in existing buildings in China were not popular before 2000 due to a lack of systematic planning by the government. In 2000, the government issued technical specifications for EERs in existing buildings. The specifications began with large-scale building retrofits in 2011 by aiming at 10 percent energy reduction per square meter for public buildings and 15 percent energy reduction for large public buildings with over $200,000 \mathrm{~m} 2$ floor area. The specifications followed with a new target for retrofitting buildings in the north area. Even so, the absence of a mandatory retrofitting code and further mandatory policies have been the most hampering factor in executing this policy ( $\mathrm{Yu}$ et al., 2014). The literature does not give further details about the China Central Government's mechanism or the number of incentivizing retrofits for existing buildings. On the other hand, China provides incentives for higher-energy-efficient appliances directly to the users, such as subsidies and trade-ins for home appliances, such as ACs, CFLs, and lighting while phasing out incandescent lamps, and to private sectors such as tax reductions for energy-efficient lighting, encourages market transformation through ESCO companies, and gives incentives for smart city investments. In overall, three case studies lesson learned can be summarized as detailed in following Table 5.

\section{CONCLUSION}

Availability of supporting policy, potential energy savings from existing building stock, and city capacity on implementing incentives in EERs are to be found as equally important factors. From data analysis above, it delivers a clear message that there are several policy issues needs to be addressed for a successful implementation of incentive in EERs in Indonesian cities. It has shown that even though green building code is existing and running, it might not work without market-based instrument-policy in place to support green building policy. With limited fiscal power, local cities government have the small ability in providing financial-type incentives.

Appropriate incentives for specific building types might contribute to the success of energy efficiency savings. Learning from Singapore experience, specific incentives for the existing building which represents the biggest number are considered as the appropriate strategy. While large and commercial buildings such as apartments, offices, and large retail stores are being built by developers who represent financial strength in this sector, non-financial type incentives might be the better options since they will add more recognition and marketing value. The latter finding is suggested for most Indonesian cities which would like to achieve EERs from the existing building, considering limitations of capacity and fiscal ability.

The essence of this research is to identify several key factors to be used in implementing EERs in Indonesian cities. From this perspective, these key factors certainly can be used further for developing a framework for EERs as the alternative financing mechanism. It might be developed further to produce a complete framework with the potential solution since each factor offers a combination of solutions that might be examined to each city situation. This flexibility of the framework would be a strength for further development.

\section{ACKNOWLEDGEMENT}

All of the authors acknowledged the important contribution from Pandita and Green Building Team from Dinas Penataan Kota (Building Authority Agency) Jakarta due to data usage permission to be analyzed by this research. 


\section{REFERENCES}

Architecture 2030., 2018. Why the Building Sector? https://architecture2030.org/buildings_problem_why/. Accessed October 19, 2018.

Berita Satu., 2015. Menpupera Terbitkan Aturan "Green Building." May 5. http://www.beritasatu.com/hunian/271355-menpupera-terbitkan-aturan-greenbuilding.html. Accessed October 9, 2018.

Biello, D., 2011. Building Retrofits: Tapping the Energy-Saving Potential. Yale Environment 360, Yale School of Forestry and Environmental Studies, November 7. https://e360.yale.edu/features/green_architecture_building_retrofits_tap_energy_saving_po tential. Accessed October 11, 2018.

Building and Construction Authority Singapore Government., 2018. Sustainable Built Environment. (n.d.). https://www.bca.gov.sg/Sustain/sustain.html. Accessed October 20, 2018.

Building Efficiency Initiative., 2010. Why Focus on Existing Buildings? April 29. https://buildingefficiencyinitiative.org/articles/why-focus-existing-buildings. Accessed October 9, 2018.

Business

Dictionary.,

n.d.

Incentive. http://www.businessdictionary.com/definition/incentive.html. Accessed October 16, 2018.

CBRE, Ltd., 2015. The New Era of Green Buildings in China. http://greeninitiatives.cn/img/white_papers/1441531986096China_Major_Report_-

_The_New_Era_of_Green_Buildings_in_China_July_2015.pdf. Accessed October 19, 2018.

Center for Clean Air Policy., 2018. Success Stories in Building Energy Efficiency. http://ccap.org/assets/Success-Stories-in-Building-Energy-Efficiency_CCAP.pdf. Accessed October 19, 2018.

Dinas Penataan Kota., 2018. Personal Interview.

Energy Sector Management Assistance Program., 2014. Financing Municipal Energy Efficiency Projects. http://www.esmap.org/node/4794. Accessed October 10, 2018.

Global Alliance for Buildings and Construction., 2016. Towards zero-emission efficient and resilient buildings, Global Status 2016. https://wedocs.unep.org/rest/bitstreams/45611/retrieve. United Nations Environment Program. Accessed October 19, 2018.

International Energy Agency., 2018. Buildings. https://www.iea.org/buildings/. Accessed October 19, 2018.

Instruksi Presiden Republik Indonesia., 2011. Instruksi Presiden Republik Indonesia Nomor 13 Tahun 2011 tentang Pengehematan Energi dan Air. August. http://popea.ebtke.esdm.go.id/regulasi/1396494274.pdf. Accessed October 10, 2018.

Jakarta Green Building., 2016. Pemerintah DKI. October 28. https://greenbuilding.jakarta.go.id/. Accessed October 9, 2018.

Jaya Raya and International Finance Corporation., 2016. Grand Design Bangunan Gedung Hijau Jakarta. https://greenbuilding.jakarta.go.id/files/granddesign/Jakarta_Grand_Design_Book.pdf. Accessed October 18, 2018.

Kementerian Energi dan Sumber Daya Mineral., 2012. Peraturan Menteri ESDM No. 13 Tahun 2012 tentang Penghematan Pemakaian Tenaga Listrik. May 29. http://jdih.esdm.go.id/peraturan/Permenpercent20ESDMpercent2013percent202012.pdf. Accessed October 9, 2018.

Kementerian Energi dan Sumber Daya Mineral., 2018. Pencabutan/penyederhanaan Regulasi dan perizinan

Sektor

ESDM.

March 
https://www.esdm.go.id/assets/media/content/content-pencabutan-penyederhanaanregulasi-dan-perizinan-sektor-esdm-.pdf. Accessed October 21, 2018.

Kompas.com., 2016. Ridwan Kamil Terbitkan Peraturan Wali Kota tentang Bangunan Gedung Hijau.

https://regional.kompas.com/read/2016/10/27/12200671/.ridwan.kamil.terbitkan.peraturan. wali.kota.tentang.gedung.hijau. Accessed October 9, 2018.

Landman, M., 1999. Breaking through the Barriers to Sustainable Building: Insights from Building Professionals on Government Initiatives to Promote Environmentally Sound Practices.

September.

https://books.google.com/books/about/Breaking_Through_the_Barriers_to_Sustain.html?id $=$ NjIkMgAACAAJ. Accessed October 16, 2018.

Philippines Green Building Council., 2018. World Green Building Week 2018. http://philgbc.org/tag/green-building-philippines/. Accessed October 16, 2018.

Republic of the Philippines, Mandaluyong City (n.d.). Ordinance No. 535, S-2014. Green Building Regulations of Mandaluyong City. http://www.mandaluyong.gov.ph/updates/downloads/files/merged.pdf. Accessed October $16,2018$.

Ruparathna, R., Hewage, K., Sadiq, R., 2016. Improving the energy efficiency of the existing building stock: A critical review of commercial and institutional buildings. Renewable and sustainable energy reviews, 53, 1032-1045.

Sweatman, P., Managan, K., 2010. Financing Energy Efficiency Building Retrofits. International Policy and Business Model Review and Regulatory Alternatives for Spain. Climate strategy partners. Online: http:/learthscience. bcsdk12. org/earthscienceiscool/media/climatechange/documents/2010\% 20Financing\% 20Energy\% 20Efficie ncy\% 20Building\% 20Retrofits. pdf.

WBCSD., 2016. EEB Laboratory - Jakarta. November 25. https://www.wbcsd.org/Programs/Cities-and-Mobility/Energy-Efficiency-inBuildings/Resources/EEB-Laboratory-Jakarta. Accessed October 10, 2018.

Wei, X., 2013. Overview of Building Codes, Building Energy Codes and Green Building Codes in China. China Academy of Building Research, March 5-7. http://mddb.apec.org/Documents/2013/SCSC/WKSP1/13_scsc_wksp1_013.pdf. Accessed October 18, 2018.

World Bank Group and GFDRR., 2015. Building Regulation for Resilience: Managing Risks for Safer

Cities. https://openknowledge.worldbank.org/bitstream/handle/10986/24438/Building0regul0sks0 forOsafer0cities.pdf. Accessed October 16, 2018.

Yu, S., Evans, M., Shi, Q., 2014. Analysis of the Chinese market for building energy efficiency. Pacific Northwest National Laboratory. Retrieved from: http://www. pnnl. gov/main/publications/external/technical_reports/PNNL-22761.pdfforhealth.org.

Zed, F., 2015. Indonesia Energy Efficiency and Conservation Status, Gaps and Opportunities. Presentation presented at Global Workshop to Accelerate Energy Efficiency Copenhagen. https://www.google.com/search?q=how+to+cite+presentation+in+apa\&rlz=1C1GGRV_en ID752ID752\&oq $=$ how + to + site + presen $\&$ aqs $=$ chrome $.2 .69 \mathrm{i} 57 \mathrm{j} 015.6535 \mathrm{j} 0 \mathrm{j} 4 \&$ sourceid $=$ chro me\&ie=UTF-8. Accessed October 21, 2018. 